\title{
Research on the Innovation Efficiency of Listed Companies Under the Influence of Equity Structure in China
}

\author{
Desheng Zhu \\ Accounting School \\ ShanDong University of Finance and Economics \\ Jinan, China
}

\author{
Xiao Chen* \\ Accounting School \\ ShanDong University of Finance and Economics \\ Jinan, China
}

\begin{abstract}
This paper selected listed companies in China before 2010 as the research sample, using the data of 2010-2015 to analyze the influence of equity structure on the enterprise innovation efficiency from the equity nature, ownership concentration, ownership balance degree aspects in China. The study found that the innovation efficiency of state-owned enterprises in China is higher than that in non-state-owned companies. There is a nonlinear relationship between the ownership concentration and enterprise innovation efficiency; as the ownership balance degree increase, enterprise innovation efficiency increase at the same time. And there is an inverted $U$ shape relationship between the proportion of the managerial ownership and enterprise innovation efficiency.
\end{abstract}

Keywords-innovation efficiency; equity nature; ownership concentration; ownership balance degree

\section{INTRODUCTION}

Innovation is not only the driving force of social and economic development, but also the guarantee of sustainable competitiveness of enterprises. The report to the 18th National Congress of the Communist Party of China put forward the strategy of innovation-driven development, which clearly indicated that scientific and technological innovation provides strategic support for raising the productivity and strengthening the comprehensive national power, and we must give it a top priority in overall national development. The Third Plenary Session of the 18th Central Committee emphasized deepening the reform of the science and technology system, fully releasing the vitality of that, and speeding up the construction of an innovative country. For a long time, Chinese enterprises have faced two difficult problems in the process of innovation: capital constraint and low efficiency of innovation. Because of the limitation of resources, improving innovation efficiency is the fundamental way which is to keep their development vitality and realize value increment for enterprise. As the foundation of corporate governance structure, ownership structure perfected is the most important thing in the process of improving comprehensive management ability, establishing modern enterprise system and strengthening internal control in China. Therefore, the purpose of this study is: how does equity structure affect the efficiency of enterprise innovation?

\section{THEORETICAL ANALYSIS AND RESEARCH ASSUMPTIONS}

\section{A. Equity Nature and Innovation Efficiency}

Several studies have shown that many governance issues in state-owned holding companies in China, such as owner absence, excessive government intervention and so on, may affect the innovation power, but the non-state-owned holding listed companies with intensive labor are mostly developed by small and medium-sized enterprises through restructuring in our country. In fact, there is insufficient innovation power because of requiring sustained capital investment, difficultly obtaining returns in the short term, high risk, and unsound system for enterprise innovation supported by the government. Furthermore, being still in the process of transition economy, China could not rely entirely on the market mechanism to guide the innovation activities of enterprises. Recently the government has increased subsidies for innovation activities, and direct government intervention in innovation activities alleviated market failure. So getting more government support in innovation subsidies and financing, state-owned holding listed companies also have more innovative resources than non-state-owned holding listed companies. Again, with the success of the split share structure reform, the conversion of non-tradable shares to tradable shares has to a certain extent solved the chronic problems of state-owned shares. Strengthening the function of the board of directors and the board of supervisor makes the level of corporate governance improve obviously, along with promoting the innovation efficiency. The above analysis presents the following assumption:

Assumption 1: state-controlled enterprises have higher innovation efficiency than non-state-holding enterprises.

\section{B. Equity Concentration and Innovation Efficiency}

When the ownership structure is too dispersed, the cost of supervision over manager's decision will be higher than the income of that, and more shareholders will choose "hitchhiking", which leads the managers to make the decision that is contrary to the maximization of shareholders' interests. Supervising the managers, the introduction of large shareholding could reduce the short-sighted behavior of managers to make them devote more attention to the long-term competitiveness brought by innovation. With the increasing shareholding ratio of the largest shareholders, the interest of the 
largest shareholders is highly consistent with that of the enterprise, so it contributes to long-term development of innovative projects, optimization of resource allocation as well as the realization of enterprise value-added cycle. Due to being faced with great uncertainty, the participation and support of large shareholders can help enterprises better grasp the opportunities and cope with risks of innovation. In addition, effectively preventing the hostile takeover of enterprises, the large shareholders can make enterprises invest in high-risk innovation projects. However, when the shareholding ratio is highly concentrated, the large shareholders will excessively intervene in the decision-making of the management for their self-interest, thus forming barrier effect. For instance, the innovation achievement is transferred privately to the wholly-owned subsidiary company to gain all the income created by the innovation achievement. Based on the above analysis, this paper proposes the following assumption:

Assumption 2: equity concentration and innovation efficiency are inversely U-shaped.

\section{Ownership Balance Degree Aspects and Innovation Efficiency}

Given that the stock rights are highly concentrated, the checks and balances of other major shareholders avoid the situation of "arbitrariness" of the largest shareholders so as to make the decision-making of enterprises more scientific. Analogously, the counterbalance ability of non-controlling shareholders determines the degree of a hindrance for controlling shareholders to use the control right to obtain private interest. The higher the degree of equity balance, the more motivation and ability of other major shareholders to supervise the behavior of the largest shareholders and corporate executives, and the stronger the hindrance to the interests of minority shareholders. But large shareholders effectively protect the interests of external investors and stop the controlling shareholders from self-interest behavior by forming a controlling alliance. Whether the equity is dispersed or not, improving the equity balance degree is beneficial to the corporate governance structure and the maintenance of enterprise value. The perfection of corporate governance structure will make enterprise management more effective, thus making the improvement of enterprise innovation efficiency. The ideal equity structure, existing in relative controlling shareholders, is a moderately concentrated ownership structure balanced by other major shareholders. For holding a considerable number of shares and gaining more than the supervision cost to jointly supervise the managers, large shareholders have an incentive to urge the executives to choose efficient innovative projects to maximize the long-term benefits of the enterprise. So the improvement of the degree of equity balance, forming effective checks and balances, alleviates the problems of "hitchhiking", and makes corporate governance more scientific to create good conditions for the improvement of innovation efficiency. Based on the above analysis, the following assumption is illustrated:

Assumption 3: equity balance helps to improve innovation efficiency.

\section{RESEARCH AND DESIGN}

\section{A. Sample Selection and Data Sources}

According to the industry classification standard of CSRC, research samples are extracted from listed companies in manufacturing and information technology industries in China. The time span is 2010-2015. This paper deals with the selected companies as follows: (1) take the companies listed before 2010 as the research sample to avoid the deviation on variable measurement caused by whitewash of statements when the companies are listed (2) exclude St and *St listed companies (3) remove the listed companies without complete data and disclosure of innovation input. Through screening a total of 4798 research samples, the research hypotheses proposed in this paper are empirically tested. In addition, the company's financial indicators, industry types and executive shareholdings stem from the CSMAR Research Database of Shenzhen Guotai an Information Technology and on the Giant Tide Information Network.

\section{B. Modeling and Variable Setting}

In order to test the hypotheses, three multivariate linear regression models are constructed as follows:

$$
\begin{aligned}
& I O E_{i}=\beta_{0}+\beta_{1} \text { State }_{i}+\beta_{2} \text { Size }_{i}+\beta_{3} R_{\text {ROA }}+\beta_{4} \text { Lev }_{i}+\beta_{5} \text { Grow }_{i}+\sum \text { Ind }+\sum \text { Year }+\mu_{i} \\
& I O E_{i}=\beta_{0}+\beta_{1} \text { SSP }_{i}+\beta_{2} \text { FSP }_{i}^{2}+\beta_{3} \text { Size }_{i}+\beta_{4} \text { ROA }_{i}+\beta_{5} \text { Lev }_{i}+\beta_{6} \text { Grow }_{i}+\sum \text { Ind }+\sum \text { Year }+\mu_{i} \\
& \text { IOE }_{i}=\beta_{0}+\beta_{1} F C B_{i}+\beta_{2} \text { Size }_{i}+\beta_{3} \text { ROA }_{i}+\beta_{4} \text { Lev }_{i}+\beta_{5} \text { Grow }_{i}+\sum \text { Ind }+\sum \text { Year }+\mu_{i}
\end{aligned}
$$

Model (1) examines the relationship between equity nature and innovation efficiency. Model (2) adds FSP2 to test the relationship between equity concentration and innovation efficiency. Model (3) lays out the influence of equity balance on innovation efficiency.

Innovation efficiency refers to the proportion between the input and output of innovation activities whose meaning is the output obtained by the unit scientific and technological innovation input under the condition of scientific and technological innovation environment and the allocation of innovative resources. The explained variable IOE is innovation efficiency, measured by the ratio of innovation output to innovation input. The innovation output, reflected by the number of patents this year, is the benefit the enterprise obtains after devoting the innovation resource, including invention patent, utility model as well as appearance design. While innovation input is divided into independent innovation input and imitation innovation input. The first one consist of one part meeting the capitalization condition as "development expenditure" in the balance sheet and the other described as "management cost" in financial statements, involving R\&D fee, technical research fee, technology development fee, R\&D expenditure, research project development fee, research project cost and so on. The later, disclosed as "management cost", mainly includes the cost of technology purchase, transformation, digestion and absorption. And the variables are defined as shown in TABLE I. 
TABLE I. LIST OF VARIABLE DEFINITIONS

\begin{tabular}{|c|c|c|c|}
\hline Type & & Name & Describe \\
\hline Explained variable & $\mathrm{IOE}$ & Innovation efficiency & Number of patents / (Independent innovation input +Imitation innovation investment) \\
\hline \multirow[t]{3}{*}{$\begin{array}{l}\text { Explanatory } \\
\text { variable }\end{array}$} & State & Equity nature & 1 for being state-owned and 0 for being no-state-owned \\
\hline & FSP & Equity concentration & Number of shares held by the first lager shareholder/Total number of shares \\
\hline & FCB & $\begin{array}{l}\text { Ownership balance degree } \\
\text { aspects }\end{array}$ & $\begin{array}{c}\text { The shareholding ratio of the second shareholder / Shareholding ratio of the first largest } \\
\text { shareholder }\end{array}$ \\
\hline \multirow[t]{6}{*}{ Controlled variable } & Size & Enterprise scale & Natural logarithm of total assets \\
\hline & ROA & Return on asset & Net profit / total asset \\
\hline & Lev & Asset-liability ratio & Total liabilities / total assets \\
\hline & Grow & Net profit growth rate & Net profit growth/ net profit last year \\
\hline & Ind & Industry & Industry virtual variable \\
\hline & Year & Year & Annual virtual variable \\
\hline
\end{tabular}

IV. FINDINGS

\section{A. Descriptive Statistical Analysis}

In this paper, the descriptive statistical analysis of variables is carried out by software Stata13, and the results are given in TABLE II.

From TABLE II, what we can see is as follows: (1) there is a great difference and low average in innovation efficiency among the enterprises in the sample. (2) The average value of State is 0.3195, which indicates that in the sample enterprises, non-state-owned holding listed companies account for a large proportion. (3) The average shareholding ratio of the largest shareholder is more than $34 \%$, the minimum value $3.39 \%$, the maximum value $88.55 \%$. This illustrates great differences in ownership concentration degree of the sample enterprises, some of which are highly controlled by controlling shareholders, and others are contrary. (4) The average value of the ratio of the second shareholder to the largest shareholder is 0.3385., in which the small value is only 0.0013 and the maximum value is 1.2149 . In fact, it sees the weak overall degree of equity checks and balances and the common phenomenon of controlling large shareholders in enterprises.

TABLE II. DESCRIPTIVE STATISTICAL ANALYSIS

\begin{tabular}{|c|c|c|c|c|c|}
\hline Variable & Obs & Mean & Std. Dev. & Min & Max \\
\hline IOE & 4798 & 0.5387 & 1.6420 & 0 & 83.3333 \\
\hline State & 4798 & 0.3195 & 0.4663 & 0 & 1 \\
\hline FSP & 4798 & 34.8862 & 14.4171 & 3.39 & 88.55 \\
\hline FCB & 4798 & 0.3385 & 0.2845 & 0.0013 & 1.2149 \\
\hline Size & 4798 & 21.8076 & 1.1170 & 19.0316 & 26.9608 \\
\hline ROA & 4798 & 0.0487 & 0.0620 & -0.4684 & 1.2015 \\
\hline Lev & 4798 & 0.3971 & 0.1991 & 0.0079 & 1.5325 \\
\hline Grow & 4798 & -0.6047 & 9.1166 & -333.2661 & 88.2787 \\
\hline
\end{tabular}

B. Multivariate Regression Analysis

In this paper, the multivariate regression analysis is carried out by software Stata13, and the results of the model are shown in TABLE III.
TABLE III. MULTIPLE REGRESSION RESULTS

\begin{tabular}{|c|c|c|c|c|c|c|}
\hline & \multicolumn{2}{|c|}{ Model (1) } & \multicolumn{2}{|c|}{ Model (2) } & \multicolumn{2}{|c|}{ Model (4) } \\
\hline & Coef. & $\mathrm{P}>|\mathrm{t}|$ & Coef. & $\mathrm{P}>|\mathrm{t}|$ & Coef. & $\mathrm{P}>|\mathrm{t}|$ \\
\hline State & $0.160 * * *$ & 0.005 & & & & \\
\hline FSP & & & $0.019 * * *$ & 0.007 & & \\
\hline $\mathrm{FSP}^{2}$ & & & $-0.001^{* * *}$ & 0.003 & & \\
\hline FCB & & & & & $0.213^{* *}$ & 0.011 \\
\hline Size & $-0.179 * * *$ & 0.000 & $-0.145 * * *$ & 0.000 & $-0.156^{* * *}$ & 0.000 \\
\hline ROA & $1.075^{* *}$ & 0.014 & $0.937 * *$ & 0.032 & $0.927^{* *}$ & 0.033 \\
\hline Lev & $0.412^{* * *}$ & 0.010 & $0.429 * * *$ & 0.007 & $0.486 * * *$ & 0.002 \\
\hline Grow & $-0.004 * * *$ & 0.009 & $-0.005^{* * *}$ & 0.008 & $-0.005^{* * *}$ & 0.008 \\
\hline Ind & \multicolumn{2}{|c|}{ controlled } & \multicolumn{2}{|c|}{ controlled } & \multicolumn{2}{|c|}{ controlled } \\
\hline Year & \multicolumn{2}{|c|}{ controlled } & \multicolumn{2}{|c|}{ controlled } & \multicolumn{2}{|c|}{ controlled } \\
\hline _cons & $3.911 * * *$ & 0.000 & $2.949 * * *$ & 0.000 & $3.388 * * *$ & 0.000 \\
\hline Sample & \multicolumn{2}{|c|}{4798} & \multicolumn{2}{|c|}{4798} & \multicolumn{2}{|c|}{4798} \\
\hline $\begin{array}{c}\text { Value of } \\
\text { F }\end{array}$ & \multicolumn{2}{|c|}{9.56} & \multicolumn{2}{|c|}{8.85} & \multicolumn{2}{|c|}{9.42} \\
\hline $\mathrm{Ad} \mathrm{R}^{2}$ & \multicolumn{2}{|c|}{0.1193} & \multicolumn{2}{|c|}{0.1193} & \multicolumn{2}{|c|}{0.1189} \\
\hline
\end{tabular}

As we can see from model (1), the explanatory variable state is obviously positive at the level of $1 \%$ significance, indicating that the innovation efficiency of state-owned holding enterprises is obviously higher than that of non-state-owned holding enterprises, and hypothesis 1 is verified. Easily supported by the government, state-owned enterprises possess more innovative resources so as to have the lower added value of production technology. As a result, state-owned controlled enterprises have higher innovation efficiency. In addition, a series of policies and measures, such as the application of modern enterprise management system, the strengthening of supervisory function of supervisory board and independent director, and the implementation of the reform of split share structure, makes the operating performance and innovation efficiency of state-owned holding enterprises improve continuously.

Model (2) introduces the two square items of the equity concentration index in order to test the nonlinear relationship between the ownership concentration and the innovation efficiency, the results of which suggest that the ownership concentration and the enterprise innovation efficiency are inverse U-shaped, supporting the assumption 2. That is, with the increase of ownership concentration, the innovation efficiency first increases and then decreases, and the regression 
coefficient of $\mathrm{FSP}^{2}$ is significant at $1 \%$. When the equity concentration is in a certain range, the interests of the large shareholders and the enterprises are highly consistent along with the increasing control of the large shareholders. So they motivate and supervise managers to maximize the value of the enterprise and to reduce the opportunistic behavior of managers.

In the model (3), the explanatory variable FCB significantly positive on the level of 5\% makes the hypothesis 3 established. The mutual balance between several large shareholders can not prevent the small shareholders from "hitchhiking", but also avoid the "one shareholder" of the large shareholders to infringe the interests of the small shareholders. The higher the balance of equity, the more motivation and ability of the shareholders to participate in the decision making, hence the decision is more scientific and the risk of the failure of the innovation investment decision is reduced.

\section{Robustness Test}

The software Stata13 is used to test the Bootstrap robustness of the model, showing the regression results in TABLE IV. In conclusion, the results of the robustness test are consistent with the results of the regression analysis, which proves the reliability of this conclusion.

TABLE IV. BOOTSTRAP TEST RESULT

\begin{tabular}{|c|c|c|c|c|c|c|}
\hline & \multicolumn{2}{|c|}{ Model (1) } & \multicolumn{2}{|c|}{ Model (2) } & \multicolumn{2}{|c|}{ Model (3) } \\
\hline & Coef. & $\mathrm{P}>|\mathrm{z}|$ & Coef. & $\mathrm{P}>|\mathrm{z}|$ & Coef. & $\mathrm{P}>|\mathrm{z}|$ \\
\hline State & $\begin{array}{c}0.160 \\
* *\end{array}$ & 0.033 & & & & \\
\hline FSP & & & $\begin{array}{c}0.019 * * \\
*\end{array}$ & 0.000 & & \\
\hline $\mathrm{FSP}^{2}$ & & & $\begin{array}{c}-0.001 * \\
* *\end{array}$ & 0.000 & & \\
\hline FCB & & & & & $\begin{array}{c}0.213^{*} \\
* *\end{array}$ & 0.002 \\
\hline Size & $\begin{array}{l}-0.17 \\
9 * * *\end{array}$ & 0.000 & $\begin{array}{c}-0.145 * \\
* *\end{array}$ & 0.000 & $\begin{array}{c}-0.156 \\
* * *\end{array}$ & 0.000 \\
\hline ROA & $\begin{array}{c}1.075 \\
* *\end{array}$ & 0.015 & $0.937 * *$ & 0.021 & $\begin{array}{c}0.927 * \\
*\end{array}$ & 0.022 \\
\hline Lev & $\begin{array}{c}0.412 \\
* * *\end{array}$ & 0.014 & $\begin{array}{c}0.429 * * \\
*\end{array}$ & 0.026 & $\begin{array}{c}0.486 * \\
* *\end{array}$ & 0.006 \\
\hline Grow & $\begin{array}{l}-0.00 \\
4^{* * *}\end{array}$ & 0.009 & $\begin{array}{c}-0.005^{*} \\
* *\end{array}$ & 0.008 & $\begin{array}{c}-0.005 \\
* * *\end{array}$ & 0.008 \\
\hline Ind & \multicolumn{2}{|c|}{ controlled } & \multicolumn{2}{|c|}{ controlled } & \multicolumn{2}{|c|}{ controlled } \\
\hline Year & \multicolumn{2}{|c|}{ controlled } & \multicolumn{2}{|c|}{ controlled } & \multicolumn{2}{|c|}{ controlled } \\
\hline Sample & \multicolumn{2}{|c|}{4798} & \multicolumn{2}{|c|}{4798} & \multicolumn{2}{|c|}{4798} \\
\hline _cons & \multicolumn{2}{|c|}{$3.911^{* * *}$} & \multicolumn{2}{|c|}{0.000} & \multicolumn{2}{|c|}{$2.949 * * *$} \\
\hline $\begin{array}{l}\text { Inspecti } \\
\text { on times }\end{array}$ & \multicolumn{2}{|c|}{500} & \multicolumn{2}{|c|}{500} & \multicolumn{2}{|c|}{500} \\
\hline Adj $R^{2}$ & \multicolumn{2}{|c|}{0.1193} & \multicolumn{2}{|c|}{0.1193} & \multicolumn{2}{|c|}{0.1189} \\
\hline
\end{tabular}

\section{CONCLUSION}

Based on the data of listed companies in manufacturing and information technology industries in China from 2010 to 2015, this paper analyzes the relationship between ownership structure and innovation efficiency in three aspects: equity nature, ownership concentration and equity balance degree. The empirical results are articulated as follows. (1)The state-owned holding company has higher innovation efficiency than the non-state-owned holding company. (2)The equity concentration is inversely U-shaped with the innovation efficiency of the enterprise. (3)There is a positive correlation between the equity balance degree and the innovation efficiency of the enterprise, meaning that equity balance helps to improve the innovation efficiency of enterprises.

From the empirical results, we can get the following enlightenment: (1) the reform of split share structure has to a certain extent solved the chronic illness of state-owned holding companies to make the governance level of state-owned holding listed companies obviously improve. At the same time, state-owned holding enterprises have gradually established a standardized modern enterprise system, paying more attention to improving their competitive advantage and long-term profitability, improving their innovation efficiency. Thus non-state-owned holding enterprises should give full play to the advantages of flexible management, cultivate the consciousness of alliance, widen the channels of financing, and make full use of the preferential policies of the state to continuously improve the ability of independent innovation. (2) Reasonable ownership structure, helping to improve the level of corporate governance and promoting enterprises to continuously improve innovation, can realize the value increment of the company, and then the company should explore more ways to improve the innovation efficiency. (3) There is a nonlinear relationship between the equity concentration degree and enterprise innovation efficiency. Only when the equity concentration degree increases moderately within a certain range, it can improve the efficiency of enterprise innovation. It is difficult to prevent the behavior of collusion between the first shareholder and the management to infringe on the interests of the minority shareholders when there is "one share alone" in an enterprise. Therefore, it is necessary to improve the degree of equity checks and balances, so that the major shareholders can restrain each other and make the decision-making more scientific to improve the efficiency of innovation to create a good internal environment.

\section{REFERENCES}

[1] Zhang, A., Zhang, Y., Zhao, R A Study of the R\&D Efficiency and Productivity of Chinese Firms. Journal of Comparative Economics, 2003 31(3): 444-464

[2] Lin, C., Lin, P., Song, F.. Property Rights Protection and Corporate R\&D: Evidence from China. Journal of Development Economics, 2010, 93(1):49-62.

[3] Hu, A. G. Z., Jefferson, G. H, A Great Wall of Patents: What is behind China' s Recent Patent Explosion. Journal of Development Economics, 2009, 90(1): 57-68

[4] Shleifer, A., Vishny, R, Large Shareholders and Corporate Control. Journal of Political Economics, 1986, 94(3): 461-488

[5] Graham, H. P Dividen Policy and Its Relationship to Investment and Financial Policies: Empirical Evidence. Journal of Business Finance and Accounting, 1985, 12(4): 531-542

[6] Gomes, A., Novaes, W, Sharing of Control as a Corporate Governance Mechanism. Pennsylvania, USA: University of Pennsylvania, Working Paper NO. 01-029, 2005

[7] Jensen, M., Meckling, W, Theory of the Firm: Managerial Behavior, Agency Costs and Ownership Structure. Journal of Financial Economics, 1976, 3(4): 305-360 
[8] Wu, J. F., Tu, R. T CEO Stock Option Pay and R\&D Spending: a behavioral agency explanation. Journal of Business Research, 2007, 60(5): 482-492

[9] Wengui Li, Minggui Yu, Ownership Structure and Innovation of Private Enterprises. Managing the World, 2015, 4: 112-125 (In Chinese)
[10] Tingqiu Cao, Wenxiang Sun, and Jianxia Yu,Capital Structure, Equity Structure, Growth Opportunities and Corporate Performance. Nankai Management Review, 2004, 7: 57-63 (In Chinese)

[11] Wen Xiao, Gaobang Lin, Government Support, R\&D Management and Technological Innovation efficiency. Managing the World, 2014: 71-80 (In Chinese) 